\title{
A Belief Questionnaire about the Nature of Mathematics for Turkish Preservice Mathematics Teachers: An Exploratory Mixed Methods Study
}

\author{
Pınar AKYILDIZ1, Yüksel DEDE² \\ ${ }^{1}$ Bartın University, Faculty of,Education, Bartın \\ ${ }^{2}$ Gazi University, Faculty of,Education, Ankara
}

ARTICLE INFO

Article History:

Received

13.03.2019

Received in revised

form 12.06.2019

Accepted

17.06.2019

Available online

30.06.2019

Article Type:

Research Article

\begin{abstract}
The purpose of this study is to develop a highly valid and reliable scale which determines pre-service mathematics teachers' beliefs towards the nature of mathematics. The study was carried out using the exploratory mixed methods. The qualitative research design of the study was conducted with a single case study and the quantitative research design was carried out with a descriptive survey study. The participants of the qualitative part of the study are 53 senior pre-service mathematics teachers, selected by convenient sampling method. The quantitative part of the study comprises 499 participants, who are pre-service mathematics teachers, selected by convenient sampling method. The data in the qualitative part of the study were collected through a feedback form which has two open-ended questions. The analysis of qualitative data was conducted by means of semantic content analysis. The results of the qualitative analysis of the study revealed that the mathematical beliefs of pre-service teachers are divided into four categories: tool-oriented, aim-oriented, progress-oriented, and function-oriented mathematical beliefs. Scale items were written based on these four categories and other relevant scale items in the literature were not used at this stage. Validity-reliability studies, exploratory factor analysis, $27 \%$ upper and lower group comparisons, item-total correlation and Cronbach's Alpha values were calculated by applying the scale items obtained from this process to the pre-service teachers. The results of the study reveal a two-factor scale with a high validity and reliability.
\end{abstract}

(c) 2019 AUJES. All rights reserved Keywords: Beliefs about the nature of mathematics, pre-service mathematics teachers, exploratory mixed methods, beliefs questionnaire.

\section{Extended Abstract}

\section{Purpose}

The researchers did not fully agree on the definition of mathematical beliefs. However, it is defined as personal assessments based on past experiences with respect to mathematics by Raymond (1997). In addition, the related literature is generally discussed in three dimensions as beliefs about the nature of mathematics, learning mathematics and teaching mathematics (see Ernest, 1989, 1991; Pajares, 1992; Raymond, 1997). Beliefs

\footnotetext{
* Corresponding author's address: Bartın University, Faculty of,Education, Bartın. e-mail: pinar.akyildiz157@gmail.com
} 
about the nature of mathematics are related to what mathematics works for and what its qualities are (Ernest, 1989; Dede \& Karakuş, 2014). These beliefs also form the basis of beliefs towards learning and teaching mathematics (Dede \& Karakuş, 2014).

There are many belief questionnaires developed in different cultures in the literature (see Schoenfeld, 1985; Grigutsch, Raatz and Törner, 1998; Charaloumbus, Philippou, \& Kyriakides, 2002; Op't Eynde \& De Corte, 2003; Beswick, 2005). On the other hand, it is observed that there are studies which make use of different qualitative and quantiative research methods to determine the mathematical beliefs of mathematics teachers (see Demirsoy, 2008; Duatepe Paksu, 2008; Toluk Uçar \& Demirsoy, 2010) or pre-service mathematics teachers (see Işıkoğlu, 2008; Haser \& Doğan, 2012; Dede \& Karakuş, 2014) in Turkey. Furthermore, in related literature, it is noticed that there are studies which were developed (see Baydar, 2000; Kayan, Haser \& Işıksal Bostan, 2013; Birgin, 2016) or adapted into Turkish (see Hacıömeroğlu, 2012; Duru \& Göl, 2016; Aydın \& Çelik, 2017) so as to determine mathematical beliefs of in-service and pre-service mathematics teachers. However, none of these questionnaires were developed specifically and comprehensively to determine the pre-service mathematics teachers' beliefs towards the nature of mathematics. In this context, the present study is a candidate to fill a gap at this point in the literature and in this study, the purpose is to develop a valid and reliable, Likert type measurement tool specific to Turkish culture, which can be used only to determine the pre-service mathematics teachers' beliefs about the nature of mathematics.

\section{Method}

This study was designed through the inventive mixed method design. While the qualitative approach of the study consists of single case study (Creswell, 2013), the quantitative approach of the study consists of screening study (Fraenkel, Wallen \& Hyun, 2011). The case in this study is the beliefs of the participants towards the nature of mathematics.

The participants of the study were selected by using different sampling methods according to the data to be collected. In this context, the sampling method and sample used at different stages of the study are summarized in Table 1.

\section{Results}

The process of developing the measurement tool which aims to determine the beliefs of pre-service mathematics teachers about the nature of mathematics is included in Table 3. At the first part of the study, the Feedback Form for the Nature of Mathematics was developed and applied in order to determine the pre-service teachers' beliefs about the 
nature of mathematics. It was determined that the pre-service teachers' beliefs about the nature of mathematics were collected in four categories.

In the second part of the study, item pool was formed in accordance with the categories obtained from qualitative data, revised by receiving expert opinion and an item pool of 43-item substance was formed. 21 senior pre-service mathematics teachers were interviewed with and the questionnaire was finalized for pilot implementation. Exploratory factor analysis (AFA) and item analysis were applied to the data of the questionnaire and the obtained values are given in Table 4 . The reliability of the questionnaire was calculated by stratified alpha coefficient (Rajaratnam, Cronbach, \& Gleser, 1965) (see Table 5).

The two factors obtained from the analyzes are called interrelated beliefs and segregated beliefs. As a result of semantic content analysis, interrelated beliefs include progress-oriented mathematical and function-oriented mathematical views while segregated beliefs encompass tool-oriented mathematical and goal-oriented mathematics views.

\section{Discussion}

The categories obtained as a result of the qualitative study are in parallel with the theoretical frameworks which were suggested in the literature before and the ones mentioned above (see. Dionne, 1984; Ernest, 1989; Grigutsch, Raatz, \& Törner, 1998). In addition, dynamic belief which is a category of the nature of mathematics of Purnomo's (2017) study is parallel to progress-oriented mathematics view, and relevant belief -in Purnomo's study- is parallel to function-oriented mathematical view in the present study. Moreover, daily life which is a factor of a questionnaire which was developed to determine the philosophical thoughts about the nature of mathematics of pre-service teachers by Sanalan et all. (2013) and the factor the beliefs about the functionality of mathematics in the study of Kandemir and Gür (2011), which is aimed at determining high school students' beliefs about mathematics coincide with the function-oriented mathematics category in the current study.

The factor structure of the questionnaire developed in this study was found to be similar to the factor structure of some questionnaires developed or adapted in the field of mathematical beliefs in the literature. For example, segregated beliefs view obtained from the present study is parallel to the static aspect of mathematics in the study of Grigutsch, et all. (1998) who worked with German Mathematics teachers and traditional beliefs in the study of Golafshani (2005) who worked with Iranian Mathematics teachers. Besides, a number of rules and processing factor of Teacher Training and Development Study (TEDS-M) coincides with segregated beliefs view in the present study. 
Similarly, the interrelated beliefs in the present study are in parallel with the dynamic aspect of mathematics in the study of Grigutsch, et al. (1998) and non-traditional beliefs in the study of Golafshani (2005). In addition, the factor of research, exploration and inference of a questionnaire which was adapted by Aydın and Çelik (2017) coincides with the dimension of related beliefs in the present study.

\section{Conclusion}

It can be stated that the abovementioned 5-Point Likert type questionnaire comprising 41 items which is developed, and undergone reliability and validity processes can significantly predict the beliefs of pre-service mathematics teachers towards the nature of mathematics. Thus, it can be successfully employed to determine Turkish pre-service mathematics teachers' beliefs towards the nature of mathematics. 


\title{
İlköğretim Matematik Öğretmen Adayları İçin Matematiğin Doğasına Yönelik İnanç Ölçeği (MDYiö): Bir Keşfedici Karma Desen Çalışması
}

\author{
Pınar AKYILDIZ1* ${ }^{*}$ Yüksel DEDE ${ }^{2}$
}

${ }^{1}$ Bartın Üniversitesi, Eğitim Fakültesi, Bartın (ic

${ }^{2}$ Gazi Üniversitesi, Gazi Eğitim Fakültesi, Ankara

MAKALE BILGI

Makale Tarihçesi:

Alındı 13.03.2019

Düzeltilmiş hali

alındı 12.06.2019

Kabul edildi

17.06.2019

Çevrimiçi yayınlandı

30.06.2019

Makale Türü:

Araştırma Makalesi

\section{ÖZET}

Bu çalışmanın amacı, ilköğretim matematik öğretmen adaylarının matematiğin doğasına yönelik inançlarını belirlemek için geçerlik ve güvenirlik düzeyi yüksek bir ölçek geliştirmektir. Çalışma, keşfedici karma desen kullanılarak yapılmıştır. Çalışmanın nitel araştırma deseni tekli durum çalışması, nicel araştırma deseni ise tarama çalışması ile yürütülmüştür. Çalışmanın nitel kısmının katılımcıları, kolay ulaşılabilir örnekleme yöntemiyle belirlenmiş olan 53 son sınıf ilköğretim matematik öğretmen adayıdır. Nicel çalışmanın katılımcıları ise kolay ulaşılabilir örnekleme yöntemiyle belirlenen 499 ilköğretim matematik öğretmen adayıdır. Çalışmanın nitel kısmındaki veriler iki açık uçlu sorudan oluşan bir görüş formu yoluyla toplanmıştır. Nitel verilerin analizi, anlamsal içerik analizi kullanılarak yapılmıştır. Çalışmanın nitel verilerinin sonuçları, öğretmen adaylarının matematiksel inançlarının, araç-odaklı, amaç-odaklı, ilerlemeodaklı ve işlev-odaklı matematiksel inançlar olmak üzere dört kategoride toplandığını ortaya koymuştur. Bu dört kategoriye dayalı ölçek maddeleri yazılmış ve bu aşamada literatürdeki diğer ilgili ölçek maddeleri kullanılmamıştır. Bu süreç sonunda elde edilen ölçek maddelerinin öğretmen adaylarına uygulanmasıyla elde edilen verilere geçerlik-güvenirlik çalışmaları, açımlayıcı faktör analizi, \%27'lik alt-üst grup karşılaştırmaları, madde-toplam korelasyonu ve Cronbach's Alpha değerleri hesaplanarak yapıımıştır. Çalışmanın sonuçları, iki faktörlü geçerlik ve güvenirlik düzeyi yüksek bir ölçeği ortaya çıkarmıştır.

(C) 2019 AUJES. Tüm hakları saklıdır Anahtar Kelimeler: Matematiğin doğasına yönelik inanç, matematik öğretmen adayları, keşfedici karma desen, inanç ölçeği.

\section{Giriş}

Bilginin doğasına ilişkin yeni kabuller, öğrenme ve öğretme süreçlerini büyük oranda etkilemiş ve eğitimde gözlemlenebilen eylemlere odaklanan davranışçı yaklaşımın eksiklikleri, bilişsel alan çalışmalarıyla ortadan kaldırılmaya çalışıımıştır. Duygu, niyet gibi içsel özelliklerle ilgilenmek isteyen bilişselcilerin çalışmaları da sadece biliş üzerine yoğunlaştığından, öğrenme sürecinde anlama, algılama ve duyuş kavramlarının eksikliği ortaya çıkmıştır (Özden, 2002).

Davranışçılar öğrenmenin edimsel, bilişselciler zihinsel sonuçlarıyla ilgilenirken duyuşsalcılar ise öğrenmenin benlik ve ahlak gelişimi sonuçlarına odaklanmıştır

\footnotetext{
*Sorumlu Yazarın Adresi: Bartın Üniversitesi, Eğitim Fakültesi, Bartın

e-posta: pinar.akyildiz157@gmail.com
} 
(Özden, 2003). Bilişsel alan, özel durumların tanımlanması ve anımsanması, işlemsel örüntüler, zihinsel yatkınlık ve becerilerin gelişimini ele alırken duyuşsal alan ilgi, tutum ve değerlerdeki değişimleri, yeterli uyum ve takdir gelişimini tanımlamayı hedefler (Committee of College and University Examiners (CCUE), 1956). Bu durum, öğretimsel içeriklerde bu boyutların birbirinden ayrıştırılmadan, birlikte ele alınmasının gerekliliğini ortaya koymaktadır. Ayrıca, matematik eğitimi literatüründe duyuşsal alandan çok davranışsal ve bilişsel alanla ilgili çalışmalar yer almaktayken son yıllarda duyuşsal alanla ilgili çalışmaların sayısında da bir artış gözlenmektedir (bkz. Grootenboer \& Hemmings, 2007). Matematik eğitiminde duyuşsal alan çalışmalarının da genellikle duygu, tutum, değer ve inanç boyutlarına odaklandığı belirtilmektedir (bkz. McLoed, 1992; DeBellis \& Goldin, 1997, 2006; Grootenboer, Lomas \& Ingram, 2008; Dede, 2012). Duygular, matematiksel etkinlikler aracılığıyla hızlıca değişen his yapılarını ifade ederken (McLoed, 1992; Goldin, 2002) tutumlar, duyguların belli bir parçasına yönelik eğilim ve uyumu ifade etmektedir (DeBellis \& Goldin, 1997, 2006). Değerler de adalet, etik ve ahlak gibi kavramları içermektedir ve kişisel gerçekler olarak da isimlendirilmektedir (McLeod, 1988, 1989; DeBellis \& Goldin, 1997; Goldin, 2002; DeBellis \& Goldin, 2006). Inançlar ise hem bilişsel hem de duyuşsal öğeler içermektedir (De Corte, Op't Eynde, \& Verschaffel, 2001; Pehkonen 2004) ve bir nesne ya da kişi hakkında tutum oluşturmanın temelini de oluştururlar (Koballa \& Glynn, 2007).

\section{İnanç ve Matematiksel İnanç}

Birçok araştırmacının üzerinde çalıştığı inanç kavramının eğitimciler ve matematik eğitimcileri tarafından uzlaşılan bir tanımı yoktur (Beswick, 2005). Bazı araştırmacılar inancın bilişsel boyutuna (bkz. Abelson, 1979; Schoenfeld, 1985; Sigel, 1985; Thompson, 1992; Törner \& Grigutsch, 1994; Markic, Eilks, \& Valanides, 2008), bazıları da duyuşsal boyutuna (bkz. Cobb, 1986; Nespor, 1987; Furinghetti \& Pehkonen, 2002; Richardson, 2003) dikkat çekerken bir kısmı da inancın hem bilişsel hem de duyuşsal boyutuna odaklanmaktadır (bkz. Hannula, 2001; Dede \& Karakuş, 2014). Bu bağlamda şimdiki çalışmada, inancın bilişsel boyutunu ön plana çıkaran "deneyimlerin oluşturduğu zihinsel yapılar" (Sigel, 1985) tanımı esas alınmıştır.

İlgili literatür incelendiğinde, matematiğe yönelik inancın tanımı üzerinde de tam olarak bir uzlaşının olmadığı görülmektedir. Örneğin, Hart (1989), Silver (1985) ve Thompson $(1982,1984)$ matematiksel inancı, matematiksel kavramlara ilişkin deneyimlerin yansıtılması olarak tanımlarken, Raymond (1997) matematikle ilgili geçmiş deneyimlere dayalı kişisel değerlendirmeler şeklinde ifade etmiştir.

Matematiksel inanç kavramı ilgili literatürde genellikle matematiğin doğasına, matematiği öğrenmeye ve matematiği öğretmeye yönelik inançlar şeklinde üç boyutta ele alınmıştır (bkz. Ernest, 1989, 1991; Pajares, 1992; Thompson, 1992; Pehkonen, 1997; Raymond, 1997; Op't Eynde, De Corte, \& Verschaffel, 2002). Ayrıca Ernest'e (1989) göre, bu inanç türleri birbiriyle ilişkilidir ve matematiğin doğasına yönelik inançlar, matematiği öğrenme ve öğretmeye yönelik inançların temelini de oluşturur (Dede \& Karakuş, 2014). Matematiğin doğasıyla ilgili inançlar, matematiğin ne işe 
yaradığı ve niteliklerinin ne olduğuyla ilgilidir (Ernest, 1989; Baydar \& Bulut, 2002; Dede \& Karakuş, 2014) ve bu inançlar için araştırmacılar tarafından farklı teorik çerçeveler ortaya atılmıştır. Örneğin bu tür inançlar, Dionne (1984), Ernest (1989) ve Grigutsch, Raatz ve Törner (1998) tarafından farklı şekillerde sınıflandırılmıştır. Dionne (1984) matematiğin doğasına yönelik inancı geleneksel, formel eğilim ve yapılandırmacı olmak üzere üç farklı alt başııta ele alırken, Ernest (1989) ise bu inancı işlemsel, Platonist ve problem çözme şeklinde üç alt kategoride incelemiştir. Grigutsch, vd. (1998) ise matematiğin doğasına yönelik inancı, formel eğilim, şema, süreç ve uygulama biçiminde dört bileşen üzerinden ele almıştır.

Araştırmacıların, matematiğin doğasına yönelik olarak yaptıkları, yukarıda verilen sınıflandırmalarının birbirleriyle benzerlikler gösterdiği söylenebilir (Liljedahl, Rolka \& Rösken, 2007). Örneğin, Ernest'in işlemsel görüşünün Dionne'nin geleneksel bakış açısı ve Grigutsch ve diğerlerinin şema boyutuyla paralellik gösterdiği söylenebilir. Bu görüşe göre, matematik terim, kural ve formüllerin bir toplamı olarak ele alınmaktadır. Yine Ernest'in Platonist görüşünün Dionne'nin formel eğilim bakış açısı ve Grigutsch ve diğerlerinin formel eğilim boyutu ile benzerlik gösterdiği söylenebilir. Bu görüşe göre matematik, aksiyomatik temeli olan ve tümdengelime dayanan kesin bir bilim dalıdır. Ernest'in problem çözme görüşü ise Dionne'nin yapılandırmacı bakış açısı ve Grigutsch ve diğerlerinin süreç boyutu kapsamında değerlendirilebilir. Bu görüşe göre ise matematik, temel olarak problem çözme süreçlerini içeren, düzen ve yapıları keşfeden, kavramlar arası ilişkilerin önemli bir rol oynadığı yapılandırmacı bir süreç olarak düşünülebilir. Grigutsch, Raatz ve Törner'ın (1998) uygulama görüşüne göre matematik toplum ve yaşam ile yakından ilişkilidir (Felbrich, Kaiser, \& Schmotz, 2014) ve bu görüş, matematiğin günlük hayattaki uygulamalarına yöneliktir. Grigutsch vd.'ne (1998) göre matematiğin doğasına yönelik belirlenen matematiğin doğasına yönelik bu dört inanç görüşü iki farklı temel bakış açısından gelmektedir: statik ve dinamik. Bu bağlamda formel eğilim ve şema görüşü, matematiğin statik yönüne, süreç ve uygulama görüşü ise matematiğin dinamik yönüne vurgu yapmaktadır.

\section{Matematik Öğretimi, Kültür ve İnanç}

İnançlar, psikolojik nesne ve olaylarla ilişkilidir ve insanların yaşadıkları çevrenin koşullarına, aynı kültürde yaşayan diğer insanlara ve bu insanlarla olan etkileşimlerine dayalı olarak farklılaşabilir (Pratt, 1992; Ekeblad \& Bond, 1994). Bu nedenle, her birey içinde yaşadığı kültüre özgü bir inanç sistemine sahip olabilir (Raymond, Santos, \& Masingila, 1991; Schommer, Calvert, Gariglietti, \& Bajaj, 1997). Bu durum, bireyin içinde yaşadığı kültürün, onun düşüncelerini ve düşünme yollarını etkilediğini göstermektedir. Benzer şekilde, insanların matematiğin doğasına ilişkin fikirleri de genellikle matematik sınıflarında ve günlük hayatlarında matematiğe ilişkin deneyimlerinden kaynaklanmaktadır (Ball, 1991). Örneğin; Anderson (1997) çalışmasında, okul kültürünün öğretmenlerin matematiksel inançlarını etkilediği sonucuna varmıştır. Ayrıca Raymond'a (1993) göre, öğretmen eğitimi programlarında edinilen deneyimler ve mevcut öğretim uygulamaları da öğretmenlerin matematiksel inançlarını etkilemektedir. Yine Raymond'a (1993) göre, öğretmenlerin matematiksel 
inançları, öğrencileri, takip ettikleri öğretim programı ve çalıştıkları okulun kültürüne göre değişmektedir ve bu durum da onların öğretim uygulamalarını farklılaştırmaktadır. Bu bağlamda, matematik öğretimi uygulamalarıyla matematiksel inançların karşılıklı olarak birbirlerini etkiledikleri, öğretim ortamının kültürünün de bu etkileşimde önemli bir faktör olduğu söylenebilir.

\section{Öğretmen ve Öğretmen Adaylarının Matematiğe Yönelik İnançları}

Öğrencilerin matematiğe karşı olumlu ya da olumsuz tutum geliştirmelerinde, öğretmenlerin ve geleceğin öğretmenleri olacak öğretmen adaylarının matematiğin doğasına yönelik inançlarının da etkisi vardır. Matematik öğretiminin geliştirilmesi için öğretmen inançlarının değerlendirilmesi ve nasıl etkilendiğinin bilinmesi gerekmektedir (Underhill, 1988). Bu noktada Pajares (1992) öğretmenlerin benimsedikleri inançların; anlayışlarını ve muhakeme yeteneklerini ve zamanla da sınıftaki davranışlarını etkilediğini belirtmektedir. Ayrıca öğretmen adaylarının sahip oldukları inançlar, onların karar verme süreçleri üzerinde de etkili olduğundan ve gerçek sınıf uygulamalarını da yönlendirdiğinden dolayı, inançların öğretim/öğrenim üzerindeki etkisi mutlaka dikkate alınmalıdır (Pajares, 1992; Brantlinger, 1996; Steinbring, 1998). Ek olarak öğretmen adaylarının sahip oldukları inançlar, onların özellikle göreve başladıkları ilk yıllarda etkili olacağından (Lester \& Garofalo, 1987) bu inançların bilinmesi önem kazanmaktadır. McDiarmid (1990), öğretmen yetiştirme programlarındaki öğretmen adaylarının inançlarının belirlenmesinin önemini ise aşağıdaki şekilde açıklamıştır:

"Bir öğretmen yetiştiricisi olarak, eğer öğrencilerimin neler düşündüklerini, üniversiteye gelirken zihinlerinde hangi fikirlerle, deneyimlerle ve inançlarla geldiklerini ve üniversitede aldıkları derslerde edindikleri fikir, deneyim ve inançların neler olduğunu bilmezsem, belirleyeceğim araçlar ve hedefler hakkında vereceğim kararlar, ortaya çıkabilecek sonuçları düşünmeden alınmış kararlar olacaktır. (p.17)"

Ülkemizdeki matematik öğretim programlarında da (ortaokul ve lise) matematiğin duyuşsal yönünün öğretme/öğrenme sürecindeki önemine dikkat çekilmiştir. Matematiğin duyuşsal boyutları tutum, değer ve özgüven özelinde dile getirilmiş ve öğretmenlere, öğrencilerde bu boyutları geliştirmelerine yönelik tavsiyelerde bulunulmuştur (Milli Eğitim Bakanlığı [MEB], 2017; MEB, 2018).

\section{Araştırmanın Amacı ve Önemi}

Literatürde farklı kültürlerde geliştirilmiş pek çok inanç ölçeği bulunmaktadır (bkz. Schoenfeld, 1985; McLoed, 1992; Grigutsch, Raatz ve Törner, 1998; Charaloumbus, Philippou, \& Kyriakides, 2002; Op't Eynde \& De Corte, 2003; Beswick, 2005). Bu ölçeklerden bazıları (bkz. Charaloumbus, Philippou, \& Kyriakides, 2002; Beswick, 2005), bireylerin matematiğin doğasına yönelik inançlarını belirlemeyi amaçlamaktadır.

Diğer taraftan, Türkiye'de matematik öğretmenlerinin (bkz. Demirsoy, 2008; Duatepe Paksu, 2008; Toluk Uçar \& Demirsoy, 2010) ya da matematik öğretmen 
adaylarının (bkz. Işıkoğlu, 2008; Haser \& Doğan, 2012; Dede \& Karakuş, 2014; Çelik, Özmen, Aydın, Güler, Birgin, Açıkyıldız, Gürsoy, Arabacı, Güneş \& Gürbüz, 2018) matematiksel inançlarının belirlenmesine yönelik nitel ve nicel araştırma yöntemlerinin kullanıldığı çalışmaların yapıldığı görülmektedir. Yine ilgili literatürde, matematik öğretmeni ve matematik öğretmeni adaylarının genel olarak matematiksel inançlarının belirlenmesine yönelik geliştirilmiş (bkz. Baydar, 2000; Güven, Karataş, Öztürk, Arslan \& Gürsoy, 2013; Kayan, Haser \& Işıksal Bostan, 2013; Sanalan, Bekdemir, Okur, Kanbolat, Baş \& Özturan Sağırlı, 2013; Birgin, 2016) ya da Türkçe uyarlaması yapılmış ölçeklerin olduğu belirlenmiştir (bkz. Hacı̈meroğlu, 2012; Duru \& Göl, 2016; Aydın \& Çelik, 2017). Ancak, bu ölçeklerden hiçbiri matematik öğretmen adaylarının sadece matematiğin doğasına yönelik inançlarını belirlemek için özel olarak ve kapsamlı bir şekilde geliştirilmemiştir. Bu bağlamda mevcut çalışma ile literatürde var olan bu boşluk doldurmaya çalışılmış ve öğretmen adaylarının sadece matematiğin doğasına yönelik inançlarını belirlemek için kullanılabilecek, Türk kültürüne özgü, geçerli, güvenilir Likert tipi bir ölçme aracının geliştirilmesi amaçlanmıştır. Zira, -yukarıda da belirtildiği üzere- içinde yaşanılan kültüre göre bireylerin inançları farklılaşabilmektedir (Raymond, Santos, \& Masingila, 1991). Bu nedenle bu tür bir ölçeğin geliştirilmesiyle, farklı kültürlerde ve öğrenme/öğretme ortamlarındaki öğretmen adaylarının matematiğin doğasına yönelik inançlarındaki olası farklılık ve benzerliklerin daha açık bir şekilde ortaya çıkarılabileceği de düşünülmektedir. Ayrıca şimdiki çalışmada geliştirilen ölçeğin keşfedici karma desen kullanılarak geliştirilmesinin de önemli olduğu düşünülmektedir. Zira ölçeğin geliştirilmesi aşamasında herhangi bir araştırmacının matematiğin doğasına yönelik daha önceden belirlediği inanç kategorileri referans noktası olarak alınmamıştır. Bunun yerine, Türk matematik öğretmeni adaylarının sahip oldukları inançlar ve bunlara ilişkin inanç kategorileri nitel veriler üzerinden ortaya çıkarılmış, bu kategoriler daha sonra nicel verilere dönüştürülmüştür.

\section{Yöntem}

Bu çalışmada, matematiğin doğasına yönelik inançları belirlemeye yönelik bir ölçeğin geliştirilmesi amaçlanmıştır. Bu nedenle çalışma, keşfedici karma yöntem deseniyle tasarlanmıştır. Keşfedici karma desende araştırmacı, nitel desene dayalı olarak bir araç geliştirir ve bu aracı nicel verileri toplarken kullanır (Creswell \& Plano Clark, 2014). Bu karma yöntem çalışmasının nitel yaklaşımını durum çalışması desenlerinden tekli durum çalışması (Creswell, 2013), nicel yaklaşımını ise betimsel araştırma desenlerinden tarama çalışması (Fraenkel, Wallen, \& Hyun, 2011) oluşturmaktadır. Bu çalışmadaki durum, adayların matematiğin doğasına yönelik inançlarıdır.

Çalışmanın katıımcıları, toplanacak verilere göre farklı örnekleme yöntemleri kullanılarak belirlenmiştir. Bu kapsamda, çalışmanın farklı aşamalarında kullanılan örnekleme yöntemi ve örneklemi Tablo 1'de özetlenmiştir. 
Tablo 1. Matematiğin Doğasına Yönelik İnanç Ölçeğini Geliştirmek Amacıyla Belirlenen Örneklemler

\begin{tabular}{ccc}
\hline Veri toplama aracı & Örnekleme Yöntemi & Örneklem \\
\hline Yazılı görüş formu & Kolay ulaşılabilir & 53 ilköğretim matematik \\
Örnekleme & öğretmen adayı (4. Sınıf) \\
Ön uygulama & Kolay ulaşılabilir & 21 ilköğretim matematik \\
(maddelerin anlaşııırlığı) & örnekleme & öğretmen adayı (4. Sınıf) \\
Pilot uygulama & Kolay ulaşılabilir & 499 ilköğretim matematik \\
(madde analizleri) & örnekleme & öğretmen adayı (4. Sınıf) \\
\hline
\end{tabular}

Tablo 1'den de görüleceği üzere, matematiğin doğasına yönelik inanç kategorilerinin belirlenmesi için İç Anadolu Bölgesi'ndeki bir devlet üniversitesinde ilköğretim matematik eğitiminin son sınıf düzeyinde eğitim gören 53 öğretmen adayına "Matematiğin Doğasına Yönelik İnanç Görüş Formu" uygulanmıştır. Bu formdan elde edilen verilerin analizi sonucunda elde edilen kategorilere yönelik inanç ölçeği madde havuzu oluşturulmuş ve uzman görüşleri alınarak ölçek maddelerinin son şekli verilmiştir. Bu maddelerin anlaşıırığının kontrolü için ise yine İç Anadolu Bölgesi'ndeki farklı bir devlet üniversitesinde öğrenim gören 21 ilköğretim matematik son sınıf öğretmen adayına bu maddeler okutulmuştur. Adaylardan gelen dönütlere göre, maddeler üzerindeki son değişiklikler yapılarak ölçeğin pilot uygulama formu oluşturulmuş ve pilot uygulama Türkiye'nin yedi coğrafi bölgesindeki kolay ulaşılabilir örnekleme yöntemiyle belirlenen sekiz devlet üniversitesinin son sınıfında öğrenim gören 499 ilköğretim matematik öğretmen adayına uygulanmıştır. Ancak ölçeği tam olarak doldurmayan (bazı maddeleri cevaplamayan), ölçekteki ikiden fazla maddeyi boş bırakan ya da ölçekteki tüm maddeler için aynı seçeneği işaretleyen 48 öğretmen adayının ölçekleri analiz dışı bırakılmıştır. Erkek öğretmen adayları için E1, E2 ve E3, kadın öğretmen adayları için ise K1, K2 ve K3 şeklinde devam eden kodlar kullanılmıştır. Bu süreç sonunda, 451 öğretmen adayının (\%77,16 kadın, \%22,84 erkek) ölçek verileri analiz edilmiştir. Burada, katıımcıların çoğunu kadın adayların oluşturması, Türkiye'deki üniversitelerdeki matematik eğitimi programlarında öğrenim gören öğrencilerin büyük çoğunluğunun kadın öğrencilerden oluşmasından kaynaklanmaktadır. 451 öğretmen adayının eğitim gördükleri üniversitelerin coğrafi bölgeleri ve cinsiyetlerine göre dağılımları ise Tablo 2'de verilmiştir. 
Tablo 2. Matematiğin Doğasına Yönelik İnanç Ölçeği Pilot Uygulaması Yapılan Adayların Üniversitelerinin Bulunduğu Coğrafi Bölge ve Cinsiyetlerine Göre Yüzde ve Frekans Dağılımları

\begin{tabular}{lcccc}
\hline $\begin{array}{l}\text { Devlet Üniversitesinin Bulunduğu } \\
\text { Coğrafi Bölge }\end{array}$ & $\mathrm{n}$ & $\%$ & Kadın & Erkek \\
\hline Güneydoğu Anadolu Bölgesi & 90 & 20 & 70 & 20 \\
Akdeniz Bölgesi & 46 & 10 & 31 & 15 \\
Ege Bölgesi & 28 & 6 & 18 & 10 \\
Marmara Bölgesi & 54 & 12 & 42 & 12 \\
Karadeniz Bölgesi & 68 & 15 & 55 & 13 \\
Doğu Anadolu Bölgesi & 92 & 21 & 74 & 18 \\
İç Anadolu Bölgesi & 73 & 16 & 58 & 15 \\
\hline TOPLAM & 451 & 100 & 348 & 103
\end{tabular}

Çalışmaya katılan öğretmen adayları, mezun olduklarında devlet okullarında ve özel kurumlarda ilköğretim matematik öğretmeni olarak çalışabilmektedirler. Adaylar, mezun olana kadar pek çok pür matematik (Genel Matematik, Soyut Matematik, Geometri, Analiz I-II-III, Lineer Cebir I-II, Analitik Geometri I-II, İstatistik ve Olasılık I-II, Cebire Giriş, Diferansiyel Denklemler, Elementer Sayı Kuramı), matematik eğitimi (Özel Öğretim Yöntemleri I-II, Matematik Tarihi, Matematik Felsefesi ve üniversite bazında matematik eğitimi seçmeli dersleri, örneğin, Problem Çözme, Matematiksel Modelleme) ve eğitim bilimleri (Eğitim Bilimine Giriş, Eğitim Psikolojisi, Öğretim İlke ve Yöntemleri, Öğretim Teknolojisi ve Materyal Tasarımı, Bilim Tarihi, Türk Eğitim Tarihi, Ölçme-Değerlendirme, Özel Eğitim, Rehberlik, Sınıf Yönetimi, Türk Eğitim Sistemi ve Okul Yönetimi) derslerini almaktadırlar. Bu bilgilerin ışığında, araştırmaya katılan ilköğretim matematik öğretmeni adaylarının, matematik öğretiminde bilişsel ve duyuşsal faktörlere ve özellikle de inanca ilişkin kapsamlı düzeyde bilgi verebilecek ve görüş bildirebilecek durumda oldukları düşünülmektedir.

\section{Ölçme Aracının Geliştirilmesi}

\section{Nitel Veriler}

Bu bölümde ilköğretim matematik öğretmen adaylarının matematiğin doğasına yönelik inançlarını belirlemeyi amaçlayan ölçme aracının geliştirilmesi sürecine yer verilmiştir (bkz. Tablo 3). 
Tablo 3. Matematiğin Doğasına Yönelik İnanç Ölçeği'ni (MDYiÖ) Geliştirme Süreci

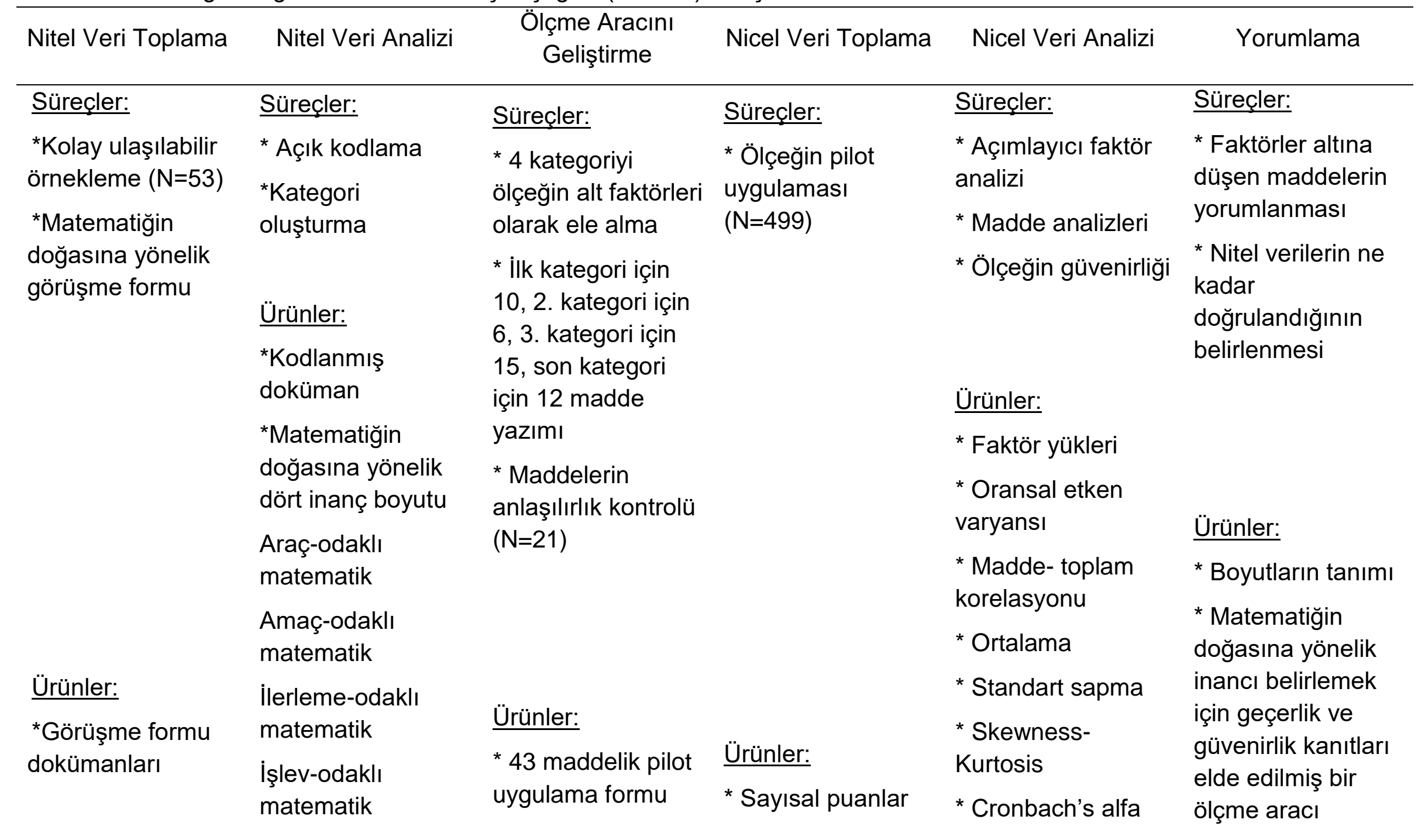


Çalışmanın ilk kısmında adayların matematiğin doğasına yönelik inançlarının nasıl olduğunu belirlemek amacıyla Matematiğin Doğasına Yönelik İnanç Görüş Formu hazırlanmıştır. Formun geliştirilmesinde, 4 matematik eğitimi uzmanının görüşlerine başvurulmuştur. Form, "Matematik deyince aklınıza ne geliyor?" ve "Matematik aracılığıyla öğrencilere (varsa) kazandırılabilecek beceriler nelerdir? Neden?" şeklinde 2 açık uçlu sorudan oluşmaktadır. Matematiğin Doğasına Yönelik İnanç Görüş Formu, 53 ilköğretim matematik öğretmenliği programı son sınıf öğrencisine uygulanmış ve elde edilen veriler, bir matematik eğitimi uzmanı ve bir ölçme-değerlendirme uzmanı (matematik eğitimi yüksek lisans mezunu) tarafından anlamsal içerik analiziyle analiz edilmiştir. Bu içerik analizi türü, analiz edilen verinin içeriğindeki asıl konu alanlarını ve bu alanlara giren özel alt alanları ortaya çıkarmak için kullanılan bir kategori oluşturma işlemidir (Tavşancıl \& Aslan, 2001).

Kategorilerin belirlenmesi için iki araştırmacı tarafından ayrı ayrı yapılan anlamsal içerik analizinde, önce her bir katılımcının cevapları tekrar tekrar okunarak kodlar belirlenmiştir. Daha sonra iki uzman belirledikleri kodları bir araya getirmiş, açıklama ve isim olarak uymayan kodlar üzerinde uzlaşıya varmışlardır. Kodlar belirlendikten sonra iki uzman yine ayrık şekilde kodları kategorileştirmişler ve ardından karşılaştırmışlardır. Aynı kategoriye atanmamış kodlar, iki uzman arasında yapılan müzakereler sonucunda aynı kategori altına yerleştirilmiştir.

Örneğin, matematik eğitimi uzmanı "tek çözüm yolu” kodunu, araç odaklı matematik kategorisi altında ele alırken, diğer uzman ise bu kodu amaç-odaklı matematik kategorisi altında ele almıştır. Yapılan görüşmeler sonucunda bu kod, araç-odaklı matematik kategorisi içine alınmıştır.

Benzer şekilde, matematik eğitimi uzmanı tarafından amaç odaklı matematik kategorisi altına konan "ilişki" kodu diğer uzman tarafından ilerleme odaklı matematik kategorisine yerleştirilmiştir. Yapılan görüşmeler sonucunda bu kod, ilerleme odaklı matematik kategorisi içinde değerlendirilmiştir. Uzmanların içerik analizlerinin karşılaştırılmasında ortaya çıkan bu tarz farklılıklar, uzmanlar tarafından tekrar birlikte ele alınmış ve her biri üzerinde uzlaşı sağlanarak uygun kategorilere yerleştirilmiştir. $\mathrm{Bu}$ süreç sonunda, uzmanlar arası uyum katsayısı, "Güvenirlik = Görüş birliği / (Görüş Birliği + Görüş Ayrılığı) x 100” formülüyle \%87 olarak hesaplandığı için ölçeğin kategorilerinin güvenilir şekilde oluşturulduğu söylenebilir (bkz. Miles \& Huberman, 1994). Kategori ve tema isimleri belirlenirken matematik eğitimi alanı uzmanı ve matematiksel inanç üzerine çalışmalar yapmış olan iki araştırmacıdan da yardım alınmıştır. Bütün bu süreç sonunda, katılımcıların matematiğin doğasına yönelik inançlarının aşağıdaki gibi 4 kategoride toplandığı görülmüştür:

a) Araç-odaklı matematik bakış açısı: $\mathrm{Bu}$ inanç türü, matematiği ilişkisiz kavramlar, işlem, formül ve kurallar toplamı olarak görmektedir. Örneğin, K24 kodlu öğretmen adayının "Matematik deyince aklıma sayılar, işlemler, fonksiyonlar, türev, integral vb. geliyor." ve K42 kodlu öğretmen adayının "Matematik dersini düşünürsem işlem algoritmaları zihnimde daha çok öne çıkıyor." ifadeleri bu kategori altında değerlendirilebilir. 
b) Amaç-odaklı matematik bakış açısı: Bu inanç türü, matematiği kesin bilgilerden oluşan, tümdengelime dayanan, sistemli ve tamamen soyut bir bilim dalı olarak ele almaktadır. Örneğin, K1 kodlu öğretmen adayının “... (matematik) sayılarla, formüllerle, denklemlerle kendi içinde tutarlı bir sistem oluşturacak şekilde adlandırımasıdır." ve K44 kodlu öğretmen adayının "... matematiğin kesin çizgilerle belirttiği yapılar da vardır ki (matematik) bu yapılar üzerine inşa edilmiştir." ifadeleri bu kategori altında değerlendirilebilir.

c) Illerleme-odaklı matematik bakış açısı: Bu inanç türüne göre, matematik keşfetmeye ve bilgi üretmeye odaklı ve diğer bilimlerle iç içe bir bilim dalıdır. Örneğin, E3 kodlu öğretmen adayının "Matematik geçmişi ve günümüzü değerlendirerek geleceği yordamamızı sağlayan, diğer bilimlerle iç içe çalışan bir bilim dalıdır.", K44 kodlu öğretmen adayının "(Matematik) Asırlardır birikimli bir şekilde günümüze kadar gelmiş ve gelişimini hala devam ettiren sürekli bir yapıdır." ve K39 kodlu öğretmen adayının "Öğrencilere matematik aracılığıyla problem çözme, mantık kurma, akıl yürütme becerileri kazandırmada kullanılabilecek bir alandır." ifadeleri bu kategori altında değerlendirilebilir.

d) İşlev-odaklı matematik bakış açısı: Bu inanç kategorisi, matematiği günlük hayatta var olan ve günlük hayat intiyaçlarını karşılamak için kullanılan bir araç olarak görmektedir. Örneğin, K20 kodlu öğretmen adayının " ... aslında matematiğin basit bir şekilde günlük hayatımızda çok fazla olduğunu düşünüyorum." ve "Herkesin matematiğe intiyacı olduğunu düşünüyorum. Ama okumamış birinin bile az da olsa matematik bildiğini düşünüyorum." ve K23 kodlu öğretmen adayının "Asında matematik sadece okuldaki dersten oluşmuyor. Matematik doğaya denktir diyebiliriz. Hayatımızın her anında, baktığımız her şeyde, doğada her yerde matematik var." ifadeleri bu kategori altında değerlendirilebilir.

\section{Nicel Veriler}

Bu kısımda, sırasıyla ölçeğin yapısı, kapsam geçerliği, pilot uygulama ve yapı geçerliğinin sağlanmasına yönelik kısa bilgilere yer verilmiştir.

\section{Ölçeğin yapısı}

Adayların Matematiğin Doğasına Yönelik İnanç Görüş Formu'na (MDYIGF) verdikleri cevaplardan elde edilen ve yukarıda bahsedilen 4 kategoriye uygun olacak şekilde iki matematik eğitimi ve bir ölçme değerlendirme uzmanlarının da görüşleri alınarak ölçek maddeleri yazılmış ve bir madde havuzu oluşturulmuştur. Ölçekte yer alan ifadeler için Kesinlikle Katılıyorum (5), Katılıyorum (4), Kararsızım (3), Katılmıyorum (2) ve Kesinlikle Katılmıyorum (1) şeklinde Likert tipi bir derecelendirme kullanılmıştır. Buradaki yüksek puanlar, matematiğin doğasına yönelik daha gelişmiş inançları temsil etmektedir.

\section{Kapsam geçerliği}

Madde havuzunun uzmanlar tarafından incelenmesi amacıyla, içinde tema adı, temanın tanımı, öğretmen adayı ifadesi ve örnek maddelerin bulunduğu bir uzman görüş formu oluşturulmuş ve bu form aracılığıyla matematiksel inanç 
konusunda çalışmaları olan 5 matematik eğitimi ve 6 ölçme-değerlendirme uzmanından dönütler alınmıştır.

Uzman dönütlerine göre, havuzdaki maddelerde bazı değişikliklere gidilmiştir. Madde silinmesi ve değişikliğinde, Miles ve Huberman (1994) uyum katsayısı dikkate alınarak, 8 ve üzeri sayıdaki uzmanın havuzda kalması yönünde görüş belirttiği maddeler havuzda olduğu gibi kalmış, değiştirilmesi yönünde bir uzlaşı sağlanan maddeler için ise uzman önerilerine göre bazı düzeltmeler yapılmıştır. Örneğin, "Matematik tümdengelime dayanır.", "Matematiksel kavramlar birbiriyle ilişkilidir." ve "Matematik evreni anlamak için bir araçtır." maddeleri, uzmanlar tarafından matematiğin doğasına yönelik inanca uygun maddeler olarak belirlenmiş ve madde havuzunda olduğu gibi bırakılmıştır. "Matematik birikimli bir bilimdir." maddesinin ise daha iyi bir şekilde ifade edilmesi gerektiği uzmanlar tarafından ifade edilmiştir. Bu nedenle bu madde, "Matematiksel bilgi, var olan bilgilerin üzerine yenileri eklenerek oluşur." şeklinde yeniden düzenlenmiştir. Benzer şekilde "Matematik problemlerinin sadece bir çözüm yolu vardır." maddesi de "Her matematik problemi sadece bir çözüm yoluna sahiptir." şeklinde revize edilmiştir.

Uzmanların madde havuzundan silinmesi yönünde görüş belirttiği maddeler ise havuzdan çıkarılmıştır. Örneğin, "Matematikte başarılı olmanın tek yolu formülleri ezberlemektir." ve "Matematiği öğrenmek için güçlü bir hafızaya sahip olmak gerekir." maddeleri, uzmanlar tarafından daha çok matematiği öğrenmeye yönelik inançlarla ilgili bulunmuş ve bu nedenle madde havuzundan çıkarılmıştır.

Ayrıca uzmanlardan gelen önerilere göre, işlev-odaklı matematik kategorisinde yer alan "Matematik teknolojinin gelişmesine katkı sağlar." ve "Matematiksel formüller yeni icatlar yapılmasını sağlar." maddeleri de ölçek madde havuzuna eklenmiş ve pilot uygulama için 43 maddelik madde havuzu oluşturulmuştur.

Havuzda yer alan maddelerin anlaşılırlığının sağlanması adına bir Türkçe eğitimi uzmanına danışılmıştır. Uzmandan alınan dönüte göre "Matematikte doğru cevap elde edildiği müddetçe, çözüm sürecinin bir önemi yoktur.” maddesi "Matematikte doğru cevap elde edildiği sürece, çözüm sürecinin bir önemi yoktur." şeklinde, "Doğru sonucu bulmak, matematikte en önemli şeydir." maddesi "Matematikte en önemli unsur, doğru sonucu bulmaktır." olarak, "İyi bir kariyer için matematik bilmek şarttır." maddesi "Matematik, iyi bir kariyer sahibi olmak için en önemli şarttır." şeklinde ve "Her matematik problemi sadece bir çözüm yoluna sahiptir." maddesi "Her matematik probleminin tek çözüm yolu vardır." olarak değiştirilmiştir.

\section{Pilot çalışma}

Ölçek maddelerinin anlaşılırlığını test etmek için 21 son sınıf ilköğretim matematik öğretmen adayı ile görüşülmüştür. Maddeler adaylara okutulmuş ve adayların maddeleri anlama durumlarına bakılmıştır. Adaylardan gelen dönütler sonucunda adayların tüm maddeleri anladıkları görülmüştür. Ancak adaylar, bazı maddelerin daha anlaşılır olması için bazı önerilerde bulunmuşlardır. Bu öneriler 
doğrultusunda, örneğin, "Matematik adaletli olmayı içerir." maddesi "Matematik, bireyleri adaletli davranmaya yönlendirir." şeklinde, "Matematik, sayılarla ifade edilir." maddesi "Matematik, sadece sayılarla ifade edilir." şeklinde "Matematik dünyayı anlamak için bir araçtır." maddesi "Matematik, evreni anlamak için bir araçtır." şeklinde ve "İyi bir kariyer için matematik bilmek şarttır." maddesi ise "Matematik, iyi bir kariyer sahibi olmak için en önemli şarttır." biçiminde değiştirilmiş ve ölçeğe uygulanması için son şekli verilmiştir.

\section{Yapı geçerliği}

Ölçek, -yukarıda bahsedilen süreçler tamamlandıktan sonra- Türkiye genelindeki devlet üniversitelerinin ilköğretim matematik öğretmenliği programı son sınıfında öğrenim gören 499 öğretmen adayına uygulanmış ve yukarıda bahsedilen gerekçelerle 451 adayın cevapları analiz için kullanılmıştır. Elde edilen verilere, açımlayıcı faktör analizi (AFA) ve madde analizleri uygulanmıştır. Öncelikle elde edilen verilerle ölçek maddelerinin AFA'ya uygun olup olmadığını anlamak için verilerin Kaiser-Mayer-Olkin (KMO) ve Bartlett's Test of Spherecity (BTS) test değerlerine bakılmıştır. Ölçekteki maddelerin ayırt edicilik düzeylerinin belirlenmesi için ise düzeltilmiş madde toplam korelasyonu hesaplanmış ve \%27'lik alt-üst grup karşılaştırmaları yapılmıştır. Her bir faktör için gruplar arası farklar t-testi ile analiz edilmiştir. Ölçeğin güvenirliğinin tespiti ise tabakalı alfa (stratified alpha) katsayısıyla (Rajaratnam, Cronbach, \& Gleser, 1965) hesaplanmıştır.

\section{Bulgular}

Toplanan ölçek verilerinin bilgisayar ortamına aktarımında olabilecek yanlışlıklar kontrol edilmiş, bir $(\mathrm{N}=25)$ ya da iki maddeyi boş bırakan $(\mathrm{N}=7)$ toplamda 32 katılımcıya ait kayıp veri olduğu tespit edilmiştir. Little's MCAR testiyle kayıp verinin tamamen tesadüfi (MCAR, Missing Completely at Random) özellikte olduğu belirlenmiştir. Daha sonra çoklu değer atama yöntemiyle (multiple imputation) kayıp veri kestirimi yapılmıştır.

Ölçeğin geçerlik ve güvenirlik kanıtlarını elde etmek için ise pilot uygulama verilerine açımlayıcı faktör analizi ve madde analizleri uygulanmıştır.

\section{Açımlayıcı faktör analizi (AFA)}

Araştırma örnekleminden elde edilen verilerin faktör analizi yapmaya uygunluğu, KMO ve BTS testleriyle belirlenmiştir. Faktör analizinin uygulanabilmesi için KMO testinin 0.50'den daha büyük değerleri kabul edilmektedir (bkz. Field, 2000) ve bu ölçme aracının KMO test sonucu 0.895 olduğundan bu veriler üzerinde yapılan faktör analizinin güvenilir sonuçlar verdiği söylenebilir. BTS test sonucunda da verilerin faktör analizi için uygun olduğu sonucuna varılmıştır ( $B=5766.673,990$, $\mathrm{p}<0.001)$.

Ölçeğin faktör yapısını belirlemek için yapılan döndürülmemiş temel bileşenler analizi (bkz. Tabachnick \& Fidell, 1996) sonucunda ölçme aracında öz değeri 1.00'den büyük 11 faktör olduğu görülmüştür. Bazı faktörlere çok az sayıda madde yüklenmesinden dolayı yamaç eğim grafiği incelenmiştir. Ancak faktör seçiminde tek 
başına yamaç eğim grafiğinin kullanılması da doğru olmadığından (bkz. Field, 2000) Maximum Likelihood ve dik döndürme (varimax) tekniği kullanılmıştır. Bu analiz sonucunda ilk faktöründe 28 madde, ikinci faktöründe 15 madde bulunan iki faktörlü bir yapı elde edilmiştir. Ancak madde analizleri sonucunda ikinci faktörde bulunan 37 .

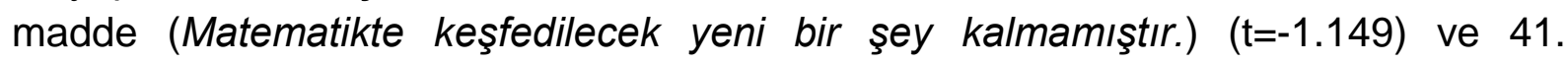
maddenin (Matematik, birbiriyle ilişkisiz kavramlardan oluşur.) ( $\mathrm{t}=-1.055)$ ölçme aracının ölçmeye çalıştığı genel yapıyı ölçmediği görülerek madde havuzundan çıkarılmıştır ( $p>0.05$ ). Bu nedenle, ikinci faktör 13 maddeden oluşmuştur. Ölçekteki maddelerin oransal ortak etken varyansı (communalities) 0.070-0.450, madde-toplam korelasyonu ise 0.318-0.669 arasında değişmektedir. İlk faktör toplam varyansın \%21,42'sini, ikinci faktör ise \%8,49'unu ve ölçeğin tamamı ise varyansın \%29,91'ini açıklamaktadır. Ölçeğin döndürülmüş faktör yükleri, oransal ortak etken varyansı, madde-toplam korelasyonu, madde ortalamaları, standart sapma ve madde ayırıcılık değerleri Tablo 4'te verilmiştir.

Elde edilen faktörler ilişkili inanç ve ayrılmış inanç olarak isimlendirilmiştir. İlişkili inanç, anlamsal içerik analizi sonucunda elde edilen ilerleme-odaklı matematik ve işlev-odaklı matematik bakışını kapsarken ayrılmış inanç ise araç-odaklı matematik ve amaç-odaklı matematik bakışını kapsamaktadır. 
Tablo 4. Matematiğin Doğasına Yönelik İnanç Ölçeği: Döndürülmüş faktör yükleri, oransal ortak etken varyansı, madde-toplam korelasyonu, madde ortalamaları, standart sapma ve madde ayırıcılık değerleri

\begin{tabular}{|c|c|c|c|c|c|c|c|}
\hline \multirow{2}{*}{ Ölçek Maddesi } & \multicolumn{2}{|r|}{ Boyut } & \multirow{2}{*}{$h^{2}$} & \multirow{2}{*}{$\begin{array}{l}\text { Madde-toplam } \\
\text { korelasyonu }\end{array}$} & \multirow{2}{*}{ Ortalama } & \multirow{2}{*}{$\begin{array}{l}\text { Standart } \\
\text { Sapma }\end{array}$} & \multirow{2}{*}{$t$} \\
\hline & IIlişkili & Ayrılmış & & & & & \\
\hline $\begin{array}{l}\text { 17. Matematik, evreni anlamamızı sağlayan bir } \\
\text { dildir. }\end{array}$ & 0.670 & & 0.450 & 0.669 & 4.28 & 0.74 & $-10.148^{\star \star}$ \\
\hline 24. Matematik, sistematik düşünmeyi içerir. & 0.665 & & 0.450 & 0.628 & 4.46 & 0.63 & $-9.140^{\star *}$ \\
\hline 11. Matematik analitik düşünmeyi içerir. & 0.652 & & 0.426 & 0.619 & 4.49 & 0.62 & $-9.639^{* *}$ \\
\hline 15. Matematik, akıl yürütmeye dayanır. & 0.649 & & 0.422 & 0.627 & 4.50 & 0.63 & $-10.474^{\star *}$ \\
\hline $\begin{array}{l}\text { 13. Matematik, günlük hayattaki etki alanını } \\
\text { sürekli genişletir. }\end{array}$ & 0.629 & & 0.396 & 0.624 & 4.23 & 0.66 & $-9.258^{\star \star}$ \\
\hline $\begin{array}{l}\text { 30. Matematik, bilgileri mantık yoluyla birbirine } \\
\text { bağlar. }\end{array}$ & 0.628 & & 0.395 & 0.608 & 4.24 & 0.62 & $-8.868^{\star \star}$ \\
\hline 20. Matematiksel kavramlar birbiriyle ilişkilidir. & 0.620 & & 0.387 & 0.595 & 4.31 & 0.59 & $-8.951^{* *}$ \\
\hline $\begin{array}{l}\text { 40. Matematik diğer disiplinler üzerindeki etki } \\
\text { alanını sürekli genişletir. }\end{array}$ & 0.611 & & 0.375 & 0.625 & 4.15 & 0.67 & $-8.634^{* \star}$ \\
\hline 9. Matematik, günlük hayatta kullanılır. & 0.603 & & 0.384 & 0.575 & 4.56 & 0.63 & $-7.115^{\star *}$ \\
\hline 21. Ölçme, matematikte önemlidir. & 0.595 & & 0.363 & 0.571 & 4.27 & 0.65 & $-9.281^{* *}$ \\
\hline 16. Matematik yaşamın kendisidir. & 0.594 & & 0.354 & 0.594 & 4.21 & 0.79 & $-9.447^{\star \star}$ \\
\hline 27. Matematik neden-sonuç ilişkisini içerir. & 0.592 & & 0.354 & 0.602 & 4.15 & 0.67 & $-9.506^{\star *}$ \\
\hline 26. Matematik, evreni anlamak için bir araçtır. & 0.582 & & 0.341 & 0.600 & 4.18 & 0.75 & $-10.015^{\star *}$ \\
\hline 32. Matematik eleştirel düşünmeyi içerir. & 0.578 & & 0.334 & 0.602 & 4.21 & 0.83 & $-10.328^{\star *}$ \\
\hline
\end{tabular}


3. Matematik teknolojinin gelişmesine katkı sağlar.

0.571

2. Matematiğin kendine özgü bir dili vardır.

0.570

35. Matematik, diğer disiplinlerle iç içedir.

23. Matematik, sürekli gelişen bir bilimdir.

0.567

0.566

10. Matematik keşfedilir.

8. Matematik soyut düşünmeyi içerir.

0.537

0.523

22. Matematik, sosyal becerilerin gelişimine katk sağlar.

0.476

34. Matematik, kültürel bir disiplindir.

0.461

38. Matematiksel formüller yeni icatlar yapıımasını sağlar.

0.407

5. Matematik, bireyleri adaletli davranmaya yönlendirir.

33. Oyun, matematiğin önemli bir parçasıdır. $\quad 0.391$

6. Matematiksel bilgi, var olan bilgilerin üzerine yenileri eklenerek oluşur.

43. Matematik, tahmin yapmayı içerir. $\quad 0.291$

29. Matematiksel bilgi, zamanla yanlışlanabilirdir. $\quad 0.250$

25. Matematikte en önemli unsur, doğru sonucu bulmaktır.

4. Matematik, formüllerin bir toplamıdır.

$\begin{array}{lllll}0.347 & 0.540 & 4.58 & 0.64 & -6.534^{\star *} \\ 0.331 & 0.547 & 4.53 & 0.58 & -8.046^{* *} \\ 0.322 & 0.581 & 4.19 & 0.77 & -8.216^{\star *} \\ 0.326 & 0.554 & 4.40 & 0.67 & -2.208^{\star *} \\ 0.290 & 0.534 & 4.31 & 0.76 & -9.202^{\star *} \\ 0.280 & 0.492 & 4.55 & 0.63 & -8.418^{\star *} \\ 0.245 & 0.500 & 3.96 & 0.80 & -8.532^{\star *} \\ 0.220 & 0.449 & 3.89 & 0.83 & -8.141^{* *} \\ 0.166 & 0.422 & 4.03 & 0.78 & -6.216^{\star *} \\ 0.194 & 0.435 & 3.77 & 0.85 & -9.573^{\star *} \\ 0.156 & 0.439 & 3.88 & 0.85 & -6.754^{* *} \\ 0.165 & 0.370 & 4.29 & 0.70 & -7.515^{\star *} \\ 0.120 & 0.333 & 3.84 & 0.84 & -6.249^{* *} \\ 0.070 & 0.318 & 3.56 & 0.99 & -3.157^{\star *} \\ 0.411 & 0.616 & 2.39 & 1.08 & -4.925^{* *} \\ 0.392 & 0.594 & 3.03 & 0.96 & -9.249^{\star *}\end{array}$


14. Matematik, kurallar bütünüdür.

18. Matematik, sadece sayılarla ifade edilir.

39. Matematik, sadece sayılardan oluşur.

31. Matematik denklemlerden oluşur.

19. Matematik tümdengelime dayanır.

36. Her matematik probleminin tek çözüm yolu vardır.

12. Matematikte doğru cevap elde edildiği sürece, çözüm sürecinin bir önemi yoktur.

7. İşlem, matematiğin en önemli parçasıdır.

28. Matematik, iyi bir kariyer sahibi olmak için en önemli şarttır.

42. Matematik, tamamen soyut bir bilimdir.

1. Matematik, kesin bilgilerden oluşur.

\begin{tabular}{llllll}
0.604 & 0.406 & 0.584 & 3.30 & 0.99 & $-10.994^{* *}$ \\
0.542 & 0.322 & 0.528 & 2.07 & 0.91 & $-4.112^{\star *}$ \\
0.537 & 0.334 & 0.512 & 1.73 & 0.84 & $-3.585^{\star *}$ \\
0.528 & 0.302 & 0.491 & 3.62 & 0.84 & $-8.021^{\star *}$ \\
0.507 & 0.263 & 0.477 & 3.29 & 0.90 & $-6.199^{\star *}$ \\
0.505 & 0.323 & 0.507 & 1.65 & 0.95 & $-2.222^{*}$ \\
0.473 & 0.252 & 0.496 & 2.01 & 1.07 & $-3.527^{\star *}$ \\
0.415 & 0.247 & 0.420 & 4.05 & 0.82 & $-9.032^{\star *}$ \\
0.375 & 0.148 & 0.437 & 3.18 & 1.14 & $-5.649^{* *}$ \\
0.331 & 0.110 & 0.415 & 2.60 & 1.06 & $-5.378^{\star *}$ \\
0.291 & 0.092 & 0.373 & 3.47 & 1.03 & $-3.695^{\star *}$ \\
\hline
\end{tabular}

${ }^{\star *} p<0.01,{ }^{\star} p<0.05$ 


\section{İç Tutarlılık (Tabakalı Cronbach's $\alpha$ )}

Elde edilen ölçek alt boyutlarının birbirleriyle ve ölçekle ilişkisine bakıldığında boyutlar arası korelasyonun 0.024 değerinde olduğu ve aralarındaki ilişkinin anlamsız olduğu ( $p>0.05$ ), ilişkili inançlar boyutunun ölçekle korelasyonu 0.868 değerinde ve aynı şekilde ayrılmış inançlar boyutunun da ölçekle korelasyonu 0.518 değerinde bulunmuş ve bu korelasyonların anlamlı olduğu görülmüştür $(p<0.01)$. Ölçeğin tamamının ve alt boyutlarının ortalama, standart sapma, varyans, iç tutarlılık (Tabakalı Cronbach's a), Skewness, Kurtosis değerleri ise Tablo 5 'te verilmiştir.

Tablo 5. Ölçek ve boyutlarının ortalama, standart sapma (SS), varyans, iç tutarlılık (Cronbach's $\alpha$ ), Skewness, Kurtosis değerleri

\begin{tabular}{cccccccc}
\hline & $\begin{array}{c}\text { Madde } \\
\text { Sayısı }\end{array}$ & Ortalama & SS & Skewness & Kurtosis & Varyans & $\alpha$ \\
\hline $\begin{array}{c}\text { İlişkili inançlar } \\
\text { Ayrılmış } \\
\text { inançlar }\end{array}$ & 28 & 4.21 & .38 & -0.92 & 4.41 & 0.15 & 0.904 \\
Ölçek toplamı & 41 & 2.80 & .48 & 0.24 & 0.70 & 0.23 & 0.741 \\
\hline
\end{tabular}

Tablo 5'ten görüleceği üzere, ölçeğin tamamı ve alt boyutlarının iç tutarlılığı sağladığı söylenebilir.

\section{Tartışma ve Sonuç}

Ölçek geliştirme sürecinde, adayların matematiğin doğasına yönelik inançlarının belirlenmesi için öncelikle bir nitel çalışma yürütülmüştür. Bu çalışma verileri, araştırmacılar tarafından geliştirilen Matematiğin Doğasına Yönelik Görüş Formu ile toplanmış ve elde edilen veriler anlamsal içerik analizine tabi tutulmuştur. Bu analiz sonucunda, matematiğin doğasına yönelik araç-odaklı matematik, amaçodaklı matematik, ilerleme odaklı matematik ve işlev odaklı matematik olmak üzere 4 inanç kategorisi elde edilmiştir. Elde edilen bu kategoriler, literatürde daha önce ortaya atılan ve yukarıda bahsedilen teorik çerçevelerle paralellik göstermektedir (bkz. Dionne, 1984; Ernest, 1989; Grigutsch, Raatz, \& Törner, 1998). Ayrıca, Purnomo'nun (2017) Endonezya'daki sınıf öğretmenleriyle çalışarak elde ettiği matematiğin doğasına yönelik inanç kategorilerinden dinamik (dynamic) inanç, şimdiki çalışmadaki ilerleme odaklı matematik; ilişkili (relevant) inanç, şimdiki çalışmadaki işlev odaklı matematik görüşüyle paraleldir. Ayrıca Sanalan, vd.'nin (2013) öğretmen adaylarının matematiğin doğasına ilişkin felsefi düşüncelerini ortaya çıkarmak için geliştirdikleri ölçeğin bir faktörü olan "günlük hayat" ve lise öğrencilerinin matematik hakkındaki inançlarını belirlemeyi amaçlayan Kandemir ve Gür'ün (2011) çalışmasındaki "matematiğin işlevselliğine yönelik inançlar" faktörü şimdiki çalışmadaki işlev odaklı matematik kategorisiyle örtüşmektedir.

Ölçek maddeleri, yapılan nitel çalışma sonucunda elde edilen kategorilere uygun şekilde yazılmıştır. Ölçeğin kapsam geçerliğini sağlamak adına ölçek 
maddeleri için matematiksel inanç konusunda çalışmış beş matematik eğitimi uzmanı ve altı ölçme-değerlendirme uzmanının görüşleri alınmıştır. Alınan dönütler sonucunda 43 maddelik pilot uygulama formu oluşturulmuştur. Bu form uygulanmadan önce 21 ilköğretim matematik öğretmen adayına okutularak maddelerin anlaşılırlık kontrolü yapılmış ve formun son şekli verilmiştir. Pilot uygulama 499 öğretmen adayıyla yürütülmüş ve analiz için 451 adayın cevapları kullanılmıştır.

Pilot uygulama sonucunda elde edilen verilere ölçeğin yapı geçerliğini sağlamak adına AFA ve madde toplam korelasyonu hesaplanmış ve \%27'lik alt-üst grup karşılaştırmaları yapılmıştır. Yapılan AFA sonucunda 43 maddelik ve iki faktörlü (ilk faktörde 28, ikinci faktörde 15 madde) bir ölçek formu elde edilmiştir. Ancak altüst grup karşılaştırmaları için yapılan t-testi sonucunda iki maddenin (37 ve 41. maddeler) ayırt edici olmadığı görülmüş ve ölçek madde havuzundan çıkarılmıştır. Çıkarılan iki maddenin ardından yeniden AFA yapılmış ve ilk faktörün toplam varyansın \%21,42'sini, ikinci faktörün \%8,49'unu açıkladığı görülmüştür. Ölçek maddelerinin faktör yükleri 0.205 ile 0.670 , oransal ortak etken varyansı 0.070 ile 0.450 , madde-toplam korelasyonu ise 0.318 ile 0.669 arasında değişmektedir.

Ölçeğin güvenirliği için Tabakalı Cronbach's a değerine bakılmıştır. Buna göre ilişkili (interrelated) inançlar boyutunun güvenirlik değeri 0.904, ayrılmış (segregated) inançlar boyutunun güvenirlik değeri 0.741 ve ölçeğin toplamının güvenirlik değeri 0.866 bulunmuştur. Buradan ölçek toplamı ve alt boyutlarının yüksek düzeyde güvenilir olduğu söylenebilir.

Ölçek öğretmen adaylarının matematiğin doğasına yönelik inanç boyutlarını ortaya çıkarmak amacıyla kullanılacağından katılımcıların Likert tipi bu ölçekten aldıkları toplam puana değil, ölçeğin boyutlarından aldıkları toplam puana odaklanılmaktadır. Ölçeğin ilişkili inançlar boyutundan alınabilecek en düşük puan 28, en yüksek puan 140; ayrılmış inançlar boyutundan alabilecek en düşük puan 13, en yüksek puan $65^{\prime}$ tir.

Ek olarak, bu çalışmada geliştirilen ve yukarıda bahsedilen geçerlik ve güvenirlik çalışmaları yapılan, beşli Likert tipinde ve 41 maddelik ölçeğin, Türk ilköğretim matematik öğretmen adaylarının matematiğin doğasına yönelik inançlarını belirlemek amacıyla kullanılabilecek geçerliği ve güvenirliği yüksek bir ölçek olduğu görülmektedir.

Araştırmanın nitel kısmından elde edilen dört kategori, inanç ölçeğindeki iki boyut altında toplanmaktadır. Araç-odaklı ve amaç-odaklı matematik kategorileri, ayrılmış inançlar boyutu altında, ilerleme odaklı ve işlev odaklı matematik ise ilişkili inançlar boyutu altında yer alabilir. Grigutsch, Raatz ve Törner'a (1998) göre de formalizm ve şema görüşleri matematiğin statik yönünü, süreç ve uygulama görüşleri ise matematiğin dinamik yönünü ifade etmektedir. Yani Alman öğretmenlerin matematiksel dünya görüşleri de iki ana görüş etrafında toplanmaktadır. 
$\mathrm{Bu}$ çalışmada ortaya çıkan faktör yapısının, literatürde matematiksel inanç alanında geliştirilen ya da uyarlanan bazı ölçeklerin faktör yapısıyla benzerlikler taşıdığı görülmüştür. Örneğin, şimdiki çalışmadan elde edilen ayrılmış inançlar boyutu, Alman matematik öğretmenleriyle çalışan Grigutsch, vd.'nin (1998) çalışmasındaki matematiğin statik yönüyle, İranlı matematik öğretmenleriyle çalışan Golafshani'nin (2005) çalışmasında matematiği kabullerden oluşan, soyut, ayrık ve işlemlerin bir toplamı olan bir alan olarak kabul eden geleneksel inançlar boyutuyla paralellik göstermektedir. Ayrıca 17 ülkede yürütülen Matematik Öğretmeni Eğitimi ve Gelişimi Çalışması (Teacher Education and Development Study, TEDS-M) için Tattoo, Schwille, Senk, Ingvarson, Peck, \& Rowley (2008) tarafından geliştirilen ve Aydın ve Çelik (2017) tarafından Türkçe'ye uyarlanan "Matematiğin Doğası Hakkındaki İnanışlar" ölçeğinin bir dizi kural ve işlem faktörü, şimdiki çalışmadaki ayrılmış inançlar boyutu ile örtüşmektedir.

Aynı şekilde şimdiki çalışmadaki ilişkili inançlar boyutu ise Grigutsch, vd.'nin (1998) çalışmasındaki matematiğin dinamik yönüyle, Golafshani'nin (2005) çalışmasında matematiği muhakemeye dayanan, insan ürünü ve diğer bilimlerle ilişkili bir alan olarak gören geleneksel olmayan inançlar boyutuyla paralellik göstermektedir. Ek olarak, Aydın ve Çelik (2017) tarafından uyarlanan ölçeğin araştırma, keşfetme ve çıkarım yapma faktörü, şimdiki çalışmadaki ilişkili inançlar boyutuyla örtüşmektedir. Buradan Türk matematik öğretmeni adaylarının matematiğin doğasına yönelik sahip oldukları inançlarının Alman ve İranlı, ayrıca TEDS-M çalışmasına katılan 17 ülkedeki (Kanada, Şili, Gürcistan, Almanya, Malezya, Norveç, Umman, Filipinler, Polonya, Rusya, Singapur, İspanya, İsviçre, Tayvan, Tayland ve ABD) matematik öğretmenlerinin inançlarıyla örtüştüğü söylenebilir.

\section{Sınırılık ve Öneriler}

Çalışmanın Türk kültürüne uygun olarak ilköğretim matematik öğretmen adaylarının matematiğin doğasına yönelik inançlarının belirlenmesi konusunda literatüre katkıları olsa da bazı sınırılıkları da mevcuttur. Öncelikle çalışmanın nitel boyutundaki katılımcılar, tek bir devlet üniversitesinin ilköğretim matematik öğretmenliği programında, son sınıfta öğrenim görmektedir. Yürütülen nitel çalışma, ülkedeki farklı üniversitelerde öğrenim gören ilköğretim ve ortaöğretim matematik öğretmen adayları ve görev yapan matematik öğretmenleriyle de görüş formu ya da mülakatlar yoluyla veri toplanarak yapılabilir. Bu şekilde hem nitel çalışma katılımcısı sayısı artırılabilir hem de daha zengin veriler elde edilebilir.

Nitel çalışmanın katılımcıları olarak ilköğretim öğretmen adayları yerine ortaöğretim matematik öğretmen adayları, ilkokul, ortaokul ve lise öğrencileri ve öğretmenlerle çalışılarak ülkemizdeki farklı grupların matematiğin doğasına yönelik inançları belirlenebilir. Ardından belirlenen bu inançların, matematik öğretmen adayı inançlarıyla benzerlik ve farklılıkları nitel olarak ortaya çıkarılabilir.

Çalışmada, ölçeğin yapı geçerliğine kanıt sağlamak için açımlayıcı faktör analizi yapılmıştır. Başka bir çalışmada, farklı ancak benzer özelliklerdeki bir 
örneklemden veri toplanıp doğrulayıcı faktör analizi yapılarak ölçeğin yapı geçerliğine yeni kanıtlar sağlanabilir.

Elde edilen ölçek yardımıyla farklı branşlardaki öğretmen adaylarının matematiğin doğasına yönelik inançlarını sınıf düzeyleri ve cinsiyetleri perspektifinden ya da matematik öğretmenlerinin matematiğin doğasına yönelik inançlarını öğretim yaptıkları sınıf düzeyleri (ortaokul ve lise), kıdemleri ve cinsiyetleri perspektifinden inceleyen farklı çalışmalar yapılabilir.

\section{Kaynaklar}

Abelson, R. (1979). Differences between belief systems and knowledge systems. Cognitive Sciences, 3, 355-366.

Anderson, J. (1997). Teachers' reported use of problem solving teaching strategies in primary mathematics classrooms. In F. Biddulph \& K. Carr (Eds.), People in mathematics education. Proceedings of the 20th Annual Conference of the Mathematics Education Research Group of Australasia (pp. 50-57). Rotorua, NZ: MERGA.

Aydın, S., \& Çelik, D. (2017). Matematiğin Doğası Hakkında İnançlar Ölçeğinin Türk Kültürüne Uyarlanması. Eğitimde Kuram ve Uygulama, 13(4), 715-733.

Ball, D. L. (1991). Research on teaching mathematics: Making subject-matter knowledge part of the equation. In J. Brophy (Ed.), Advances in research on teaching Vol. 2. Teacher's knowledge of subject matter as it relates to their teaching practice. A research annual (pp. 1-48). Greenwich, CT: Jai Press.

Baydar, C. S. (2000). Beliefs of preservice mathematics teachers at the Middle East Technical University and the Gazi University about the nature of mathematics and the teaching of mathematics. Middle East Technical University. Ankara.

Baydar, S. C. ve Bulut, S. (2002). Öğretmenlerin matematiğin doğası ve öğretimi ile ilgili inançların matematik eğitimindeki önemi. Hacettepe Üniversitesi Eğitim Fakültesi Dergisi, 23, 62- 66.

Beswick, K. (2005). The beliefs/practice connection in broadly defined contexts. Mathematics Education Research Journal, 17(2), 39-68.

Birgin, O. (2016). Matematik öğrenmeye ilişkin inanç ölçeğinin geliştirilmesi: Geçerlik ve güvenirlik çalışması. Proceedings of $1^{\text {st }}$ INES Academic Research Congress (ss. 663-3670). Ankara: Pegem Akademi Yayıncılık.

Brantlinger, E. (1996). Influence of preservice teachers' beliefs about pupil achievement on attitudes toward inclusion. Teacher Education and Special Education: The Journal of the Teacher Education Division of the Council for Exceptional Children, 19(1), 17-33.

Charalambous, C., Philippou, G., \& Kyriakides, L. (2002). Towards understanding teachers' philosophical beliefs about mathematics. 
Cobb, P. (1986). Contexts, goals, beliefs, and learning mathematics. For the Learning of Mathematics, 6(2), 2-9.

Committee of College and University Examiners. (1956). Taxonomy of educational objectives (Vol. 1). New York: David McKay.

Creswell, J. W. \& Plano Clark, V. L. (2014). Karma yöntem araştırmaları tasarımı ve yürütülmesi (Y. Dede \& S. B. Demir, Çev. Edt.). Ankara: Anı Yayıncılık. (Orijinal çalışmanın yayınlanması 2011).

Creswell, J. W. (2013). Nitel araştırma yöntemleri beş yaklaşıma göre nitel araştırma ve araştırma deseni (M. Bütün \& S. B. Demir, Çev. Edt.). Ankara: Siyasal Kitapevi. (Orijinal çalışmanın yayınlanması 2013).

Çelik, D., Özmen, Z. M., Aydın, S., Güler, M., Birgin, O., Açıkyıldız, G., Gürsoy, K., Arabacı, D., Güneş, G., \& Gürbüz, R. (2018). İlköğretim matematik öğretmeni adaylarının matematik hakkındaki inançlarının ulusal düzeyde karşılaştırılması. Eğitim ve Bilim, 43(193).

De Corte, E., Op't Eynde, P., \& Verschaffel, L. (2002). Knowing what to believe: The relevance of students' mathematical beliefs for mathematics education. Lawrence Erlbaum Associates.

DeBellis V. A. \& Goldin, G. A. (1997). The affective domain in mathematical problemsolving. In E. Pehkonen (Ed.). Proceedings of the 21st Conference of the International Group for the Psychology of Mathematics Education, vol. 2, (pp. 209-216). Lahti, Finland.

DeBellis, V. A. \& Goldin, G. A. (2006). Affect and meta-affect in mathematical problem solving: A representational perspective. Educational Studies in Mathematics, 63(2), 131-147.

Dede, Y. \& Karakuş, F. (2014). Matematik öğretmeni adaylarının matematiğe yönelik inançları üzerinde öğretmen eğitimi programlarının etkisi. Kuram ve Uygulamada Eğitim Bilimleri, 14(2), 1-23.

Dede, Y. (2012). Students' attitudes towards geometry: a cross-sectional study. Jornal Internacional de Estudos em Educação Matemática, 5(1).

Demirsoy, N. H. (2008). Ilköğretim matematik öğretmenlerinin matematik hakkındaki inançları, uygulamaları ve arasındaki ilişki. (Yayımlanmamış yüksek lisans tezi). Abant İzzet Baysal Üniversitesi/Sosyal Bilimler Enstitüsü, Bolu.

Dionne, J. (1984). The perception of mathematics among elementary school teachers. In J. Moser (Ed.), Proceedings of the 6th Annual Meeting of the North American Chapter of the International Group for the Psychology of Mathematics Education (PME). Madison (WI): University of Wisconsin, pp. 223-228. 
Duatepe Paksu, A. (2008). Öğretmenlerin matematik hakkındaki inançlarının branş ve cinsiyet bakımından karşılaştırılması. Hacettepe Üniversitesi Eğitim Fakültesi Dergisi, 35, 87-97.

Duru, A., \& Göl, R. (2016). Öğretmen Adaylarının Matematik, Matematik Öğretimi ve Matematik Öğrenmeye İlişkin İnançları. Adıyaman Üniversitesi Eğitim Bilimleri Dergisi, 6(2), 255-282.

Ekeblad, E, \& Bond, C. (1994) The nature of a conception: questions of context, in R. Ballantyne \& C. Bruce (Eds) Phenomenography: philosophy and practice (Brisbane, Queensland University of Technology, Centre for Applied Environmental and Social Education Research), 343-353.

Ernest, P. (1989). The knowledge, beliefs, and attitudes of the mathematics teacher: A model. Journal of Education for Teaching, 15(1), 13-33.

Ernest, P. (1991). The philosophy of mathematics education. New York: Falmer Press.

Felbrich, A., Kaiser, G. ve Schmotz, C. (2014). The cultural dimension of beliefs: An investigation of future primary teachers' epistemological beliefs concerning the nature of mathematics in 15 countries. S. Blömeke, F. J. Hsieh, G. Kaiser ve W. H. Schmidt (Ed.), in International perspectives on teacher knowledge, beliefs and opportunities to learn TEDS-M Results (s. 209-229). Springer.

Field, A. (2000). Discovering statistic using SPSS for Windows. Londra: Sage Publication.

Fraenkel, J. R., Wallen, N. E., \& Hyun, H. H. (2011). How to design and evaluate research in education. New York: McGraw-Hill Humanities/Social Sciences/Languages.

Furinghetti, F., \& Pehkonen, E. (2002). Rethinking characterizations of belief. In G. Leder, E. Pehkonen, \& G. Törner (Eds.), Beliefs: A hidden variable in mathematics education? (pp. 39- 58). Dordrecht: Kluwer Academic Publishers.

Golafshani, N. (2005). Secondary teachers' professed beliefs about mathematics, mathematics teaching, and mathematics learning: Iranian perspective. Unpublished doctoral dissertation. Ontario Institute for Studies in Education of the University of Toronto, Canada.

Goldin, G. A. (2002). Affect, meta-affect, and mathematical belief structures. In G. Leder, E. Pehkonen, \& G. Törner (Eds.), Beliefs: A hidden variable in mathematics education? (pp. 59 -72), Dordrecht: Kluwer Academic Publishers.

Grigutsch, S., Raatz, U., \& Törner, G. (1998). Einstellungen gegenüber Mathematik bei Mathematiklehrern (Mathematics teachers' epistemological beliefs about the nature of mathematics). Journal für Mathematik-Didaktik (Journal of Mathematics Education), 19, 3-45. 
Grootenboer, P. J., \& Hemmings, B. (2007). Mathematics performance and the role played by affective and background factors. Mathematics Education Research Journal, 19(3), 3-20.

Grootenboer, P., Lomas, G. \& Ingram, N. (2008). The affective domain and mathematics education. In H. Forgasz, A. Barkatsas, A. Bishop, B. Clarke, S. Keast et al (eds.), Research in mathematics education in Australasia 20042007 (pp. 255-269). Rotterdam, The Netherlands: Sense Publishers.

Güven, B., Karataş, I., Öztürk, Y., Arslan, S. \& Gürsoy, K. (2013). A study of scale development on determination of pre-service and in-service teachers' beliefs about pre-school mathematics education. Elementary Education Online, 12(4), 969-980.

Hacıömeroğlu, G. (2012). Matematik inanç ölçeğinin Türkçe'ye uyarlama çalışması. Journal of the Cukurova University Institute of Social Sciences, 21(3), 175184.

Hannula, M. S. (2001, June). Students' needs and goals and their beliefs. I. In Current state of research on mathematical beliefs X Proceedings of the MAVI10 European Workshop (pp. 25-32).

Hart, L. E. (1989). Describing the affective domain: Saying what we mean. In Affect and Mathematical Problem Solving (pp. 37-45). Springer New York.

Haser, Ç., \& Doğan, O. (2012). Pre-service mathematics teachers' belief systems. Journal of Education for Teaching, 38(3), 261-274.

Işıkoğlu, N. (2008). The effects of a teaching methods course on early childhood preservice teachers' beliefs. Journal of Early Childhood Teacher Education, 29(3), 190-203.

Kandemir, M. A., \& Gür, H. (2011). Ortaöğretim öğrencilerinin matematik hakkındaki inançlarını belirlemeye yönelik matematik inanç ölçeği: geçerlik ve güvenirlik çalışması. Education Sciences, 6(2), 1490-1511.

Kayan, R., Haser, Ç., \& Işıksal Bostan, M. (2013). Matematik öğretmen adaylarının matematiğin doğası, öğretimi ve öğrenimi hakkındaki inanışları. Eğitim ve Bilim, 38(167).

Koballa, T. R., \& Glynn, S. M. (2007). Attitudinal and motivational constructs in science learning. In S. K. Abell \& N. G. Lederman (Eds.), Handbook of research on science education (pp. 75-102). Mahwah: Lawrence Erlbaum.

Lester, F. K., \& Garofalo, J. (1987). The influence of affects, beliefs, and metacognition on problem solving behavior: Some tentative speculations. Paper presented at the annual meeting of American Educational Research Association, Washington, D.C.

Liljedahl, P., Rolka, K. \& Rösken, B. (2007). Affecting affect: The re-education of preservice teachers' beliefs about mathematics and mathematics learning and 
teaching. G. W. Martin, M. E. Strutchens, and P. C. Elliott (Eds), in 69th NCTM year book (s. 319-330). Reston, VA: NCTM.

Markic, S., Eilks, I., \& Valanides, N. (2008). Developing a tool to evaluate differences in beliefs about science teaching and learning among freshman student teachers from different science teaching domains: a case study. Eurasia Journal of Mathematics, Science \& Technology Education, 2, 109-120.

McDiarmid, G. W. (1990). Challenging prospective teachers' beliefs during early field experience: A quixotic undertaking? Journal of Teacher Education, 41(3), 1220.

McLeod, D. B. (1988). Affective issues in mathematical problem solving: Some theoretical considerations. Journal for Research in Mathematics Education, 134-141.

McLeod, D. B. (1989). Beliefs, attitudes, and emotions: New views of affect in mathematics education. In Affect and mathematical problem solving (pp. 245258). Springer, New York, NY.

McLeod, D. B. (1992). Research on affect in mathematics education: A reconceptualization. Handbook of research on mathematics teaching and learning, 575-596.

Miles, M. B., \& Huberman, M. (1994). Qualitative data analysis: An expanded sourcebook. Sage.

Milli Eğitim Bakanlığı [MEB]. (2017). Matematik Dersi Öğretim Programı (İlkokul ve Ortaokul 1, 2, 3, 4, 5, 6, 7 ve 8. Sınıflar). Ankara.

Milli Eğitim Bakanlığı [MEB]. (2018). Matematik Dersi Öğretim Programı (Illkokul ve Ortaokul 1, 2, 3, 4, 5, 6, 7 ve 8. Sinıflar). Ankara.

Nespor, J. (1987). The role of beliefs in the practice of teaching. Journal of Curriculum Studies, 19(4), 317-328.

Op't Eynde, P., \& De Corte, E. (2003). Students' Mathematics-Related Belief Systems: Design and Analysis of a Questionnaire.

Op't Eynde, P., De Corte, E., \& Verschaffel, L. (2001). What to learn from what we feel? The role of students' emotions in the mathematics classroom.

Özden, Y. (2002). Eğitimde yeni değerler: Eğitimde dönüşüm. Ankara: PegemA Yayıncilık.

Özden, Y. (2003). Öğrenme ve öğretme. Ankara: PegemA Yayıncılık.

Pajares, M. F. (1992). Teachers' beliefs and educational research: Cleaning up a messy construct. Review of Educational Research, 62(3), 307-322.

Pehkonen, E. (1997). Teachers conceptions on mathematics teaching. 5. Proceedings of the MAVI-5 Workshop on the Current State of the Research on Mathematical Beliefs, University of Helsinki, Finland. 
Pehkonen, E. (2004). State-of-art in mathematical beliefs research. In M. Niss (Ed.), Proceedings of the 10th International Congress on Mathematical Education (pp. 1-14). Roskilde, Denmark: Roskilde University.

Pratt, D. D. (1992). Conceptions of teaching, Adult Education Quarterly, 42(4), 203220.

Purnomo, Y. W. (2017). A Scale for Measuring Teachers' Mathematics-Related Beliefs: A Validity and Reliability Study. International Journal of Instruction, 10(2), 23-38.

Rajaratnam, N., Cronbach, L. S., \& Gleser, G. C. (1965). Generalizability of stratifiedparallel tests. Psychometrika, 30, 39-56.

Raymond, A. M. (1993). Unraveling the relationships between beginning elementary teachers' mathematics beliefs and teaching practices. Proceedings of the 15th Annual Conference of the International Group for the Psychology of Mathematics Education, Monterey, CA. (ERIC Document Reproduction Service No. ED 390694.)

Raymond, A. M. (1997). Inconsistency between a beginning elementary school teacher's mathematics beliefs and teaching practice. Journal for Research in Mathematics Education, 28(5), 550-576.

Raymond, A., Santos, V., \& Masingila, J. (1991). The Influence of Innovative Instructional Processes on Mathematical Belief Systems. Paper presented in Annual Meeting of the American Educational Research Association. https://files.eric.ed.gov/fulltext/ED390703.pdf

Richardson, V. (2003). Preservice teachers' beliefs. In J. Rath \& A. C. McAninch (Eds.), Advances in teacher education series, (pp. 1-22). Greenwich, CT: Information Age.

Sanalan, V. A., Bekdemir, M., Okur, M., Kanbolat, O., Baş, F. \&Sağırlı, M. Ö. (2013). Öğretmen adayların matematiğin doğasına ilişkin düşünceleri. Pamukkale Üniversitesi Eğitim Fakültesi Dergisi, 33(33), 155-168.

Schoenfeld, A. H. (1985). Mathematical problem solving. Orlando, FL: Academic Press.

Schommer, M., Calvert, C., Gariglietti, G. and Bajaj, A. (1997). The Development of Epistemological Beliefs Among Secondary School Student: A Longitudinal Study. Journal of Educational Psychology, 89(1), 37-40.

Sigel, I. E. (1985). A conceptual analysis of beliefs. In I. E. Sigel (Ed.), Parental belief systems: The psychological consequences for children (pp. 345-371). Hillsdale, NJ: Erlbaum.

Silver, E. A. (1985). Teaching and learning mathematical problem solving: Multiple research perspectives. Hillsdale, NJ: Erlbaum. 
Steinbring, H. (1998). Elements of epistemological knowledge for mathematics teachers. Journal of Mathematics Teacher Education, 1(2), 157-189.

Tabachnick, B. G., \& Fidell, L. S. (1996). Using multivariate statistics. Harper Collins. New York.

Tattoo, M. T., Schwille, J., Senk, S., Ingvarson, L., Peck, R., \& Rowley, G. (2008). Teacher Education and Development Study in Mathematics (TEDS-M): Conceptual framework. East Lansing: Teacher Education and Development International Study Center, College of Education, Michigan State University.

Tavşancıl, E. ve Aslan, A. E. (2001). Sözel, yazılı ve diğer materyaller için içerik analizi ve uygulama örnekleri. İstanbul: Epsilon Yayınları.

Thompson, A. G. (1982). Teachers' conceptions of mathematics and mathematics teaching: Three case studies. Doctoral dissertation, University of Georgia.

Thompson, A. G. (1984). The relationship of teachers' conceptions of mathematics and mathematics teaching to instructional practice. Educational Studies in Mathematics, 15(2), 105-127.

Thompson, A. G. (1992). Teachers' beliefs and conceptions: A synthesis of the research In D. A. Grouws (Ed.), Handbook of research on mathematics teaching and learning (s. 127-146), New York: Macmillian.

Toluk Uçar, Z., \& Demirsoy, N. H. (2010). Eski-yeni ikilemi: matematik öğretmenlerinin matematiksel inançları ve uygulamaları. Hacettepe Üniversitesi Eğitim Fakültesi Dergisi, 39(39), 321-332.

Törner, G., \& Grigutsch, S. (1994). Mathematische Weltbilder bei studienanfängerneine erhebung. Journal für Mathematik-Didaktik, 15(3-4), 211-251.

Underhill, R. (1988). Focus on research into practice in diagnostic and prescriptive mathematics: mathematics learners' beliefs: a review. Focus on Learning Problems in Mathematics, 10(1), 55-69. 